\title{
Time and Cost Overrun in the Saudi Arabian Oil and Gas Construction Industry
}

\author{
Abdulaziz Bin Seddeeq ${ }^{1}$, Sadi Assaf ${ }^{1}$, Abdullatif Abdallah ${ }^{2} \odot$ and Mohammad A. Hassanain ${ }^{3, *}$ \\ 1 Construction Engineering and Management Department, King Fahd University of Petroleum and Minerals, \\ Dhahran 31261, Saudi Arabia; 3deesn@gmail.com (A.B.S.); sadiassaf@gmail.com (S.A.) \\ 2 Department of Management and Marketing, King Fahd University of Petroleum and Minerals, \\ Dhahran 31261, Saudi Arabia; abdullatif.s.abdallah@gmail.com \\ 3 Architectural Engineering Department, King Fahd University of Petroleum and Minerals, Dhahran 31261, \\ Saudi Arabia \\ * Correspondence: mohhas@kfupm.edu.sa; Tel.: +966-13-860-3283
}

Received: 2 December 2018; Accepted: 2 February 2019; Published: 8 February 2019

check for updates

\begin{abstract}
Many construction projects exceed time and budget. The Saudi Arabian construction projects are not an exception to this phenomenon. However, the causes of time and cost overrun of Saudi Arabian oil and gas construction projects have never been studied. Thus, this paper endeavors to investigate the main causes of time and cost overrun in Saudi Arabian oil and gas construction projects. Thirty-eight causes of time and cost overrun were identified through the literature and an interview. Responses from 48 professionals based in the Eastern Province of Saudi Arabia were obtained. The respondents were solicited to evaluate the significance of the causes, which were then ranked and a test of agreement was conducted. All survey participants agreed that the five major causes of time and cost overrun, combined, were found to be "changing of design and scope by client during construction", "poor planning and scheduling of project", "design errors", "Inadequate comprehension of scope of work at the bidding stage", and "underestimating of cost and schedules/overestimating of benefits". On the other hand, the major cause of time overrun was found to be "changing of design and scope by client during construction". Finally, the major cause of cost overrun was found to be "underestimating of cost and schedules/overestimating of benefits", respectively. The findings of this study will be beneficial to project stakeholders who must operate in an industry that is highly sensitive. The findings will also facilitate organizations planning to conduct construction projects in the Saudi Arabian oil and gas industry.
\end{abstract}

Keywords: oil and gas industry; time and cost overrun; construction projects

\section{Introduction}

Project management, as stated by Oberlender [1], refers to the coordination of a company's resources and schedule in order to have a given project completed within an agreed upon time and budget. According to Jackson [2], the construction industry is notorious for having projects that experience cost overruns. Similarly, Ahmed [3] notes that overruns on construction projects are a universal phenomenon. Construction project delays adversely affect the project stakeholders (owner, contractor, consultant) in terms of increasing adversarial relationships, distrust, litigation, arbitration, cash-flow problems, and a general feeling of apprehension towards each other.

The oil and gas industry represents the backbone of the Saudi national economy. To understand the crucial role of the oil and gas industry in terms of its contribution to the gross domestic product (GDP) of the country, it is sufficient to realize that it accounts for $42 \%$ of GDP, $90 \%$ of exports and $86 \%$ of budget revenues. The Saudi oil and gas market has generated around $\$ 63$ billion of total revenues 
during 2015. Despite the plan of the Saudi government to reduce the dependence on the oil and gas industry, it is anticipated that the revenue of this market will increase by $39.4 \%$ by 2020 to generate a value of $\$ 87.8$ billion [4].

During the last four decades, Saudi Arabia has witnessed exceptional growth in the oil and gas construction projects. Major oil and gas development projects have been constructed in industrial cities such as Jubail and Yanbu. This includes construction of plants, oil and gas refineries, construction of pipelines, well oil setups for extraction, petrochemical manufacturing industries and other utilities.

The industry is highly technical and sensitive in nature. Furthermore, it involves implementation in remote areas, which requires different levels of communication. These projects also have a high degree of technical complexity. In light of this, to make them more manageable, projects are usually divided into smaller segments. However, this requires integration of various technical fields to accomplish the main goals of the project. Other complexities include specialist procurement, management and operational systems. Furthermore, these projects have aspects which are common with other construction projects, such as the rapid growth, tight construction time schedules, production process shut down, special structural features, involvement of international contractors and consultants, and multinational workforce $[5,6]$.

A large body of previous studies has investigated the topic of time and cost overrun. Kaming et al. [7] studied the factors impacting construction time and cost overruns in high-rise buildings based in Indonesia. It was found that the major factors contributing to time overruns were "design changes", "poor labour productivity", "inadequate planning", and "inadequate planning", and "resource shortages". With respect to cost overruns, findings revealed that "material cost increases due to inflation", "inaccurate materials estimating", and "degree of project complexity" were the four major factors. Flyvbjerg et al. [8], who studied causes of cost overruns in transportation infrastructure, concluded that duration of the "implementation phase" had a strong influence on the cost escalation of the referenced project type. In Saudi Arabia, Assaf and Al-Hajji [9] studied the causes of delays of construction projects in general. The study concluded that "change order" was the most frequent cause of delay. In China, Lo et al. [10] demonstrated that "inadequate resources due to contractor/lack of capital" led to construction delays of civil engineering projects. In light of the above brief overview of the literature, it can be noted that most of the earlier studies conducted in this research area have focused on time and cost overrun in infrastructure projects, civil projects, high-rise building projects, and construction projects in general [7-11]. Moreover, there exists a paucity of previous studies that have discussed the current topic in the context of the oil and gas industry. Further still, in Saudi Arabia, there exists no prior study of time and cost overrun in the oil and gas industry.

The specific purpose of this study, then, is to bridge this knowledge gap by identifying the most significant causes of time and cost overrun of oil and gas construction projects in the Eastern Province of Saudi Arabia. This region represents a good case study because a large number of construction projects associated with oil and gas industry are constructed in the Eastern Province of Saudi Arabia.

\section{Methodology}

This section discusses the methodology that was adopted to investigate the time and cost overrun of construction projects in the oil and gas industry.

- Identify main causes of time and cost overruns from previous studies in various countries and industries. To ensure a comprehensive coverage of all relevant causes, the top ranked and frequently cited causes in the literature were aggregated. These causes were adopted as presented in these previous studies with no modifications to the original names, whereas, in some cases, the causes were modified to avoid ambiguity. Moreover, to maximize the validity of the identified causes, the causes cited in studies based on the oil and gas industry were assigned more weight. Next, the pool of identified causes was filtered such that the causes that were deemed to be inapplicable to the Saudi Arabian construction industry were eliminated. For example, government financial difficulties, shortage of construction materials, and floods were omitted as 
they were deemed to be irrelevant to the study area. Finally, other parameters were introduced based on the opinion of a professional with extensive experience in the Saudi Arabian oil and gas industry. The opinion of the mentioned subject matter expert was obtained to verify the validity, relevance and clarity of the proposed factors. The consulted expert was judged to be in the best position to provide useful insights given his extensive years of experience in the field as well as his experience working as a client, contractor and consultant. Such a unique blend of experience and broad perspective was difficult to find.

- Develop a questionnaire survey in order to assess the level of significance of the identified causes. The respondents were requested to assess the significance of the 38 identified causes based on their experience in the industry. This was accomplished with the aid of a 5-point Likert scale, with 5 corresponding to "extremely significant" and 1 to "insignificant".

- Obtain responses from 48 oil and gas industry professionals practicing in the Eastern Province of Saudi Arabia. These professionals included 10 contractors, 26 consultants and 12 owners. The purpose of conducting this exercise was to gain an understanding on the main causes of time and cost overrun in oil and gas construction projects, as viewed by the industry professionals.

- Classify causes based on the source of cause for analysis purposes. This classification system led to grouping the 38 identified causes into seven categories. These seven categories are:

- All parties-related causes: causes induced directly or indirectly by all parties

$\bigcirc$ Consultant/designer-related causes: causes induced directly or indirectly by consultant/designer contribution in the project.

- Contract-related causes: causes influenced by policies of contracting and definition of parties' relationship, as stated in the contract.

- Contractor-related causes: causes induced directly or indirectly by contractor performance in the project.

- External-related causes: external causes such as environment; macroeconomic; government regulations and laws; and market conditions.

- Owner-related causes: causes induced directly or indirectly by owner's policies and procedures in the project.

Resources-related causes: causes related to manpower (labor), raw material, and equipment.

- Classify causes based on time overrun and cost overrun separately.

- Analyze causes by computing significance index and ranking.

\section{Previous Studies}

It has been noted that the most important elements for the success of any project are cost, time and quality [12]. Atkinson [13] referred to these elements as the "iron triangle". Therefore, a project is considered successful if it is completed within budget, schedule, and as per user expectations and specifications [14]. According to Avots [15], cost overrun occurs "when the final cost of project exceeds original estimate or budget" [16].

There is a strong correlation between delay in projects and cost overrun. Therefore, causes of project delay are eventually causes of cost overrun in most cases [17]. This was clearly shown to be the case by Sambasivan and Soon [18] who found that cost overrun was ranked second as a product of project delay. Furthermore, some researchers have treated delay and cost overrun as a one quality [19-21].

In Flyvbjerg et al. [22], the authors performed a statistical study of the cost performance of transportation projects. The study analyzed a significant sample of 258 projects across 20 different countries, with a combined cost of around $\$ 90$ billion. These projects were constructed between 
1925 and 2000. The findings of this study were alarming in that they revealed that out of every ten transportation infrastructure projects, nine suffered from cost overrun.

In a subsequent follow up study, Flyvbjerg et al. [8] investigated the causes of cost overrun of these projects. The scope of the study was to investigate the correlation between cost overrun, and the duration of the project, size of the project, and type of ownership of the project. It was concluded that a strong positive correlation between implementation duration of a project and cost overrun existed. In addition, in larger projects, the cost escalation was found to be higher (in terms of percentage) than smaller projects.

\subsection{Time and Cost Overruns in Developing Countries}

There has been a limited number of studies on time and cost overrun in developing countries. According to Bella [23], there is a need for such studies in order to formulate suitable solutions, which can be applied in the construction industry to avert unnecessary cost.

In Nigeria, Mansfield et al. [24] revealed that the main causes of cost escalation of construction project were "finance and payment arrangements", "poor contract management", "materials shortages", "inaccurate estimating", and "overall price fluctuations".

In Indonesia, Kaming et al. [7] conducted a study on the impact factors of high-rise building projects. It was found that "inflationary increases in material cost", "inaccurate material estimating" and "project complexity" were major factors that led to cost overrun.

In Ghana, Frimpong et al. [25] revealed the main causes of time and cost overruns in groundwater construction projects were "monthly payment difficulties from agencies", "poor contractor management", "material procurement", "poor technical performances", and "escalation of material prices".

In Vietnam, Le-Hoai et al. [20] concluded that the five most significant causes of time and cost overruns were "poor site management and supervision", "poor project management assistance", "financial difficulties of owner", "financial difficulties of contractor", and "design changes".

In Palestine, Enshassi et al. [26] found the three main causes of construction projects cost overruns were "price fluctuations of construction materials", "contractor delays in material and equipment delivery", and "inflation".

In Uganda, Alinaitwe et al. [21] found that the five most significant causes of delays and cost overruns in public sector projects were "changes in the work scope", "delayed payments to contractors", "poor monitoring and control", and "high inflation and interest rates".

In Egypt, Abd El-Razek et al. [27] found the major causes of delay in construction projects were "financing by contractor during construction", "delays in contractor's payment by owner", "design changes by owner or his agent during construction", "partial payments during construction", and "nonutilization of professional construction/contractual management".

\subsection{Time and Cost Overruns in the Saudi Arabian Construction Industry}

In Saudi Arabia, cost overrun sometimes occurs because of poor estimation of cost involved in the construction project. This may be owing to the practice in governmental bidding projects of generally awarding projects to the lowest bidder [28].

Zamel [29] conducted a study on cost control techniques adopted by contractors in the Eastern Province of Saudi Arabia. The study found that cost control was affected primarily by company and project characteristics.

Also in Saudi Arabia, Al-Dubaisi [30] conducted a study to investigate the effects and causes of change orders in building projects. The results indicated that projects that experienced change orders had cost overruns that ranged between 6 to $10 \%$ of the total cost of the project, and time overruns of about $10 \%$ of the total contract duration.

Another study by Assaf and Al-Hajji [9], also based in the Eastern Province of Saudi Arabia, investigated 73 factors to identify the major causes for delay of construction projects. The study 
revealed that the majority of the respondents estimated the average time overrun in construction projects ranged between 10 to 30 percent of project planned duration, and that more than $70 \%$ of construction projects experienced time overrun. The top ranked cause in this study was change order.

\subsection{Time and Cost Overrun in the Oil and Gas Industry}

Although limited in number, there have been a number of studies that have explored the issue of time and cost overruns in the oil and gas industry. This suggests that this sensitive industry is not impervious to scourge of cost overrun.

A study conducted by Thuyet et al. [31] aimed to identify the main risks factors of construction projects in the oil and gas industry based in Vietnam. The factors that were identified as major risks in these construction projects were "bureaucratic government system and long project approval procedures", "poor design", "incompetence of project team", "inadequate tendering practices", and "late internal approval processes from the owner".

Fallahnejad [32] conducted a study in the Iranian natural gas industry to identify the causes of delay in pipeline construction projects. The study revealed that the top ten causes of time overrun in projects were "imported materials", "unrealistic project duration", "client-related materials", "land expropriation", "change orders", "contractor selection methods", "payment to contractor", "obtaining permits", "suppliers' cash flow", and "contractor's cash flow".

In Oman, Ruqaishi and Bashir [33] conducted a study to investigate the main causes of delay of construction projects in the oil and gas industry. The results showed that the main causes of delays were "poor site management and supervision by contractors", "problems with subcontractors", "inadequate planning and scheduling of the project by contractors", "poor management of contractors' schedules", "delay in delivery of materials", "lack of effective communication among project stakeholders", and "poor interaction with vendors in the engineering and procurement stages". It was noted that the last cause was unique to the oil and gas industry.

Another recent study by Derakhshanalavijeh and Teixeira [34] investigated the cost overrun of the Iranian oil and gas industry. The result of this study showed that the most significant factors which contributed to cost overrun were "inaccurate cost estimations", "improper planning", "frequent design changes", "inadequate labour/skill availability", "inflation of costs of machinery", "labour, raw material and transportation prices". Table 1 presents a summary of the reviewed literature.

In light of the above literature review, it is clear that the causes of time and cost overrun in construction projects vary from one country to another. Moreover, there is a lack of studies that investigate the causes of construction projects' time and cost overrun in the oil and gas industry of developing countries. Furthermore, a smaller portion of these studies is based in the Middle East, and none in Saudi Arabia. Given this knowledge gap, the following study contributes to the literature by directly addressing the causes of time and cost overrun of construction projects in the oil and gas industry of Saudi Arabia. The study also investigates the role of each of the project's stakeholders in contributing to time and cost overruns. 
Table 1. Summary of major causes of time and cost overrun in the reviewed literature.

\begin{tabular}{|c|c|c|c|}
\hline Reference & Country & Industry & Major causes of time and cost overrun \\
\hline [7] & Indonesia & High-rise buildings & $\begin{array}{l}\text { Time: } \\
\text { "design changes", "poor labour productivity", "inadequate planning", and "inadequate } \\
\text { planning", and "resource shortages" } \\
\text { Cost: } \\
\text { material cost increases due to inflation", "inaccurate materials estimating", and "degree of } \\
\text { project complexity" }\end{array}$ \\
\hline [24] & Nigeria & Construction project & $\begin{array}{l}\text { Cost } \\
\text { "finance and payment arrangements", "poor contract management", "materials shortages", } \\
\text { "inaccurate estimating", and "overall price fluctuations" }\end{array}$ \\
\hline [25] & Ghana & Ground water & $\begin{array}{l}\text { "monthly payment difficulties from agencies", "poor contractor management", "material } \\
\text { procurement", "poor technical performances", and "escalation of material prices" }\end{array}$ \\
\hline [20] & Vietnam & Building and industrial projects & $\begin{array}{l}\text { "poor site management and supervision", "poor project management assistance", "financial } \\
\text { difficulties of owner", "financial difficulties of contractor", and "design changes" }\end{array}$ \\
\hline [26] & Palestine & Construction projects & $\begin{array}{l}\text { "price fluctuations of construction materials", "contractor delays in material and equipment } \\
\text { delivery", and "inflation". }\end{array}$ \\
\hline [21] & Uganda & Public sector projects & $\begin{array}{l}\text { "changes in the work scope", "delayed payments to contractors", "poor monitoring and control", } \\
\text { and "high inflation and interest rates" }\end{array}$ \\
\hline [27] & Egypt & Construction projects & $\begin{array}{l}\text { "financing by contractor during construction", "delays in contractor's payment by owner", } \\
\text { "design changes by owner or his agent during construction", "partial payments during } \\
\text { construction", and "nonutilization of professional construction/contractual management" }\end{array}$ \\
\hline [9] & Saudi Arabia & Construction projects & Change order \\
\hline [10] & China & civil engineering projects & $\begin{array}{l}\text { "Inadequate resources due to contractor/lack of capital", "Unforeseen ground conditions", } \\
\text { "Exceptionally low bids", "Inexperienced contractor", "Works in conflict with existing utilities" }\end{array}$ \\
\hline [32] & Iran & Pipeline construction projects & $\begin{array}{l}\text { "imported materials", "unrealistic project duration", "client-related materials", "land } \\
\text { expropriation", "change orders" }\end{array}$ \\
\hline [33] & Oman & Oil and gas & $\begin{array}{l}\text { "poor site management and supervision by contractors", "problems with subcontractors", } \\
\text { "inadequate planning and scheduling of the project by contractors", "poor management of } \\
\text { contractors' schedules", "delay in delivery of materials" }\end{array}$ \\
\hline [34] & Iran & Oil and gas & $\begin{array}{l}\text { "inaccurate cost estimations", "improper planning", "frequent design changes", "inadequate } \\
\text { labour/skill availability", "inflation of costs of machinery" }\end{array}$ \\
\hline
\end{tabular}


Table 1. Cont.

\begin{tabular}{|c|c|c|c|}
\hline Reference & Country & Industry & Major causes of time and cost overrun \\
\hline [35] & Zambia & road construction projects & $\begin{array}{l}\text { Cost } \\
\text { "bad or inclement weather due to heavy rains and floods", "scope changes", "environmental } \\
\text { protection and mitigation costs", "schedule delay", "strikes" } \\
\text { Time } \\
\text { "delayed payments", "financial processes and difficulties on the part of contractors and clients", } \\
\text { "contract modification", "economic problems", "materials procurement" }\end{array}$ \\
\hline [36] & Malaysia & Construction projects & $\begin{array}{l}\text { "cash flow problems faced by the contractors" and "late payment from contractors to } \\
\text { sub-contractors or suppliers" }\end{array}$ \\
\hline [37] & Tanzania & Construction projects & $\begin{array}{l}\text { Causes of delay } \\
\text { "design changes", "delays in payment to contractors", "information delays", "funding } \\
\text { problems", "poor project management", compensation issues and disagreement on the valuation } \\
\text { of work done. }\end{array}$ \\
\hline
\end{tabular}




\section{Assessment of Causes of Time and Cost Overrun}

To measure the significance of a certain cause, the significant index was employed [38]. The following formula was used to compute this index:

$$
\text { S.I }=\frac{\sum_{1}^{5} a_{i} n_{i}}{N}
$$

where: $a_{i}$ : constant that expresses the degree of significance assigned to each response, where $a_{1}=1$; $\mathrm{a}_{2}=2 ; \mathrm{a}_{3}=3 ; \mathrm{a}_{4}=4 ; \mathrm{a}_{5}=5 . \mathrm{n}_{\mathrm{i}}$ : frequency of each response, and $\mathrm{N}$ : total number of responses.

The proposed weights were adopted based on several previous studies, for example $[39,40]$ among others.

Determination of the appropriate sample size is a crucial stage in ensuring the reliability of any survey. The first step in determining this sample size is to define the population of the survey. In this study, the population is restricted by three criteria:

- Respondent must be a contractor, consultant or owner in the oil and gas industry.

- Respondent must be a project manager, engineer, or manager with experience in oil and gas construction projects.

- Respondent must be practicing in the Eastern Province of Saudi Arabia.

In this study, three statistical parameters were employed in determining the required sample size, namely, confidence level, margin of error, and standard of deviation. Using a $95 \%$ confidence level and a $\pm 15 \%$ margin of error, while assuming the sample was normal distributed, the required sample size was determined to be 43 respondents. Accordingly, responses to the questionnaire survey were obtained from 48 respondents. This sample comprised 26 consultants, 12 owners, and 10 contractors. This sample size was considered to be adequate when compared to similar previous studies. For example, Mansfield et al. [24] had a sample size of 37, Thuyet et al. [31] had a sample size of 42, and Fallahnejad [32] had a sample size of 23.

With respect to the sample distribution based on owner type, $68.8 \%$ of the respondents were involved in private projects, $27.1 \%$ were involved in governmental project, $47.1 \%$ were involved in semi-governmental projects, and $2.1 \%$ were involved in other projects. With respect to the sample distribution based on the position occupied by the respondents, $45.83 \%$ of the respondents held engineering positions, $31.25 \%$ held managerial positions, $14.58 \%$ held managerial/engineering positions, and $8.33 \%$ held other positions. With respect to the sample distribution based on the respondents' years of experience in the industry, $37.50 \%$ of the respondents had less than five years of experience, $54.16 \%$ of the respondents had between 5 to 14 years of experience, and $8.33 \%$ had more than 20 years of experience.

\section{Findings}

According to the responses of the questionnaire survey, the top five ranked causes of time and cost overrun in construction projects in the oil and gas industry in Saudi Arabia are "changing of design and scope by client during construction" (owner), "poor planning and scheduling of project" (all parties), "design errors" (consultant), "Inadequate comprehension of scope of work at the bidding stage" (contractor), and "underestimating of cost and schedules/overestimating of benefits" (owner). When compared to previous studies, the findings of this study concur with that of Alinaitwe et al. [21] and Abd El-Razek et al. [27], which concluded that the cause "changes in the work scope" and "design changes by owner or his agent during construction" were among the most significant causes of time and cost overruns."

The top five ranked factors for each party is presented in Table 2. The factor "changing of design and scope by client" which was ranked first overall, was ranked first by owners, second by contractors, and fifth by consultants. These results indicate that the oil and gas industry is highly sensitive to any change in scope of a project. This could be attributed to the highly complex nature of these types of 
projects, permitting small margin for changes. "Poor planning and scheduling of project", which was ranked second overall, was ranked third by all parties. This reinforces the previous observation of the first cause. These projects are highly complex, therefore making careful planning and scheduling imperative for a successful outcome. Finally, the factor "design errors" which was ranked third overall, was ranked fifth and fourth by the owners and consultants, respectively. This is a valid result since improper design strongly influences the planning and scheduling of these projects.

It is interesting to note that, in all cases, the parties did not primarily attribute the cause of time and cost overrun to causes associated with their own categories. This is evident from the top five causes ranked by each of the three parties. However, it is clear that there is a level of accountability, as can be seen by the top ranked causes of the owner and contractor, which fall under their category. The consultant, however, ranked the only cause among the top five causes associated with them fourth.

Table 2 also presents the in-group ranking of the causes. The category "all parties-related causes" consists of three causes. The most significant cause under this category was "poor planning and scheduling of project", with a significance index of 3.72. The least significant cause under this category was "personality clash between two or more members from different parties" with a significance index of 2.40.

The category "consultant/designer-related causes" consists of seven causes. The most significant cause under this category was "design errors", with a significance index of 3.65. "Design errors" is most the significant cause under this category because of the nature of construction projects in the oil and gas industry, demanding high levels of coordination and integration between different design disciplines. As such, any design error could have devastating implications on the development of a given project. The least significant cause under this category was "Inadequate management of contractor's schedule by consultant", with a significance index of 3.03. This finding could be due to the fact that many contractors have their own management, planning and scheduling teams, who oversee construction activities. Thus, it is not always the case that the contractor's schedule is managed by consultants.

The category "contract-related causes" consists of four causes. The most significant cause under this category was "Poor communication among the parties", with a significance index of 3.48. This reveals the importance of effective communication and understanding among the project stakeholders for the realization of a successful project. The least significant cause under this category was "Poorly defined payment milestones", with a significance index of 3.10.

The category "contractor-related causes" consists of nine causes. The most significant cause under this category was "Inadequate comprehension of scope of work at the bidding stage", with a significance index of 3.58. This may be owing to the fact that an incomplete understanding of the project's scope could lead to underbidding. Alternatively, the contractor might secure a project in which they lack the competency to complete. In either case, the contractor suffers, experiencing time and cost overruns. The least significant cause under this category was "Financing project by contractor during construction", with a significance index of 2.93.

The category "external-related causes" consists of three causes. The most significant cause under this category was "variations in market conditions", with a significance index of 2.96. The least significant cause under this category was "Impact of hot weather on construction work", with a significance index of 2.47 .

The category "owner-related causes" consists of eight causes. The most significant cause under this category was "design and scope change by client during construction", with a significance index of 3.79. The least significant causes under this category were "adoption of fast-track project delivery strategy" and "poor definition of subsurface data", with significance indices of 2.97.

The category "resources-related causes" consists of four causes. The most significant cause under this category was "material procurement issues", with a significance index of 3.48. The least significant cause under this category was "Labors' lack of skills and productivity", with significance indices of 2.96.

The 38 identified causes were divided into two major groups, namely, time overrun and cost overrun causes, while maintaining the same subcategories. The purpose of this grouping was to assess the significant causes contributing to cost and time overruns of oil and gas projects, separately. 
Table 2. Overall, owners, contractors and consultant significant index of causes of time and cost overrun.

\begin{tabular}{|c|c|c|c|c|c|c|c|c|c|c|}
\hline \multirow[b]{2}{*}{ No. } & \multirow[b]{2}{*}{ Causes } & \multirow[b]{2}{*}{ SI } & \multicolumn{2}{|c|}{$\begin{array}{l}\text { Overall } \\
(\mathrm{n}=48)\end{array}$} & \multicolumn{2}{|c|}{$\begin{array}{l}\text { Owners } \\
(\mathrm{n}=12)\end{array}$} & \multicolumn{2}{|c|}{$\begin{array}{l}\text { Contractors } \\
(\mathrm{n}=10)\end{array}$} & \multicolumn{2}{|c|}{$\begin{array}{l}\text { Consultants } \\
(\mathrm{n}=26)\end{array}$} \\
\hline & & & $\mathbf{R}_{\mathrm{G}}$ & $\mathbf{R}_{\mathbf{O}}$ & SI & $\mathbf{R}_{\mathbf{O}}$ & SI & $\mathbf{R}_{\mathbf{O}}$ & SI & $\mathbf{R}_{\mathbf{O}}$ \\
\hline \multicolumn{11}{|c|}{ All Parties-related causes } \\
\hline 1 & Incompetent project team & 3.35 & 2 & 12 & 3 & 26 & 3.6 & 10 & 3.44 & 13 \\
\hline 2 & $\begin{array}{l}\text { Personality clash between two or more members from } \\
\text { different parties }\end{array}$ & 2.40 & 3 & 38 & 2.11 & 38 & 2.875 & 36 & 2.22 & 38 \\
\hline 3 & Poor planning and scheduling of project & 3.72 & 1 & 2 & 3.64 & 3 & 3.8 & 3 & 3.73 & 3 \\
\hline \multicolumn{11}{|c|}{ Consultant/designer-related causes } \\
\hline 4 & Design errors & 3.65 & 1 & 3 & 3.55 & 5 & 3.7 & 6 & 3.69 & 4 \\
\hline 5 & $\begin{array}{l}\text { Inadequate cost estimating approach / inaccurate material } \\
\text { estimation }\end{array}$ & 3.34 & 2 & 13 & 3.3 & 9 & 3.3 & 23 & 3.42 & 15 \\
\hline 6 & Inadequate quality control/assurance & 3.34 & 3 & 14 & 3.18 & 16 & 3.6 & 8 & 3.23 & 21 \\
\hline 7 & Negligence of site visits before/during the bidding process & 3.32 & 4 & 16 & 3.2 & 14 & 3.56 & 12 & 3.2 & 23 \\
\hline 8 & $\begin{array}{l}\text { Inadequate management of contractor's schedule by } \\
\text { consultant }\end{array}$ & 3.03 & 7 & 27 & 2.78 & 29 & 3.22 & 25 & 3.08 & 28 \\
\hline 9 & Unforeseen conditions and structural modifications & 3.29 & 5 & 18 & 3.3 & 10 & 3.4 & 19 & 3.16 & 24 \\
\hline 10 & Weak and insufficient technical studies & 3.28 & 6 & 19 & 3.11 & 18 & 3.44 & 15 & 3.28 & 18 \\
\hline \multicolumn{11}{|c|}{ Contract-related causes } \\
\hline 11 & Poor communication among the parties & 3.48 & 1 & 7 & 3.73 & 2 & 3.3 & 20 & 3.42 & 14 \\
\hline 12 & Discrepancies in contract documents & 3.19 & 3 & 23 & 3 & 25 & 3.1 & 32 & 3.46 & 11 \\
\hline 13 & Poorly defined payment milestones & 3.10 & 4 & 26 & 2.5 & 33 & 3.7 & 5 & 3.09 & 27 \\
\hline 14 & $\begin{array}{l}\text { Lack of communication with suppliers in the engineering } \\
\text { and procurement phases }\end{array}$ & 3.45 & 2 & 8 & 3.55 & 4 & 3.5 & 13 & 3.29 & 17 \\
\hline \multicolumn{11}{|c|}{ Contractor-related causes } \\
\hline 15 & Financing project by contractor during construction & 2.93 & 9 & 35 & 2.33 & 35 & 3.22 & 24 & 3.25 & 20 \\
\hline 16 & Inadequate or insufficient contractor experience & 3.30 & 4 & 17 & 3 & 23 & 3.3 & 22 & 3.6 & 7 \\
\hline 17 & Poor project implementation strategies & 3.20 & 5 & 21 & 3.2 & 15 & 3.2 & 29 & 3.21 & 22 \\
\hline 18 & Inadequate management and supervision of site & 3.42 & 2 & 9 & 3 & 22 & 4 & 1 & 3.25 & 19 \\
\hline
\end{tabular}


Table 2. Cont

\begin{tabular}{|c|c|c|c|c|c|c|c|c|c|c|}
\hline \multirow[b]{2}{*}{ No. } & \multirow[b]{2}{*}{ Causes } & \multirow[b]{2}{*}{ SI } & \multicolumn{2}{|c|}{$\begin{array}{l}\text { Overall } \\
(\mathrm{n}=48)\end{array}$} & \multicolumn{2}{|c|}{$\begin{array}{l}\text { Owners } \\
(\mathrm{n}=12)\end{array}$} & \multicolumn{2}{|c|}{$\begin{array}{l}\text { Contractors } \\
(\mathbf{n}=10)\end{array}$} & \multicolumn{2}{|c|}{$\begin{array}{l}\text { Consultants } \\
(\mathrm{n}=26)\end{array}$} \\
\hline & & & $\mathbf{R}_{\mathrm{G}}$ & $\mathbf{R}_{\mathbf{O}}$ & SI & $\mathbf{R}_{\mathbf{O}}$ & SI & $\mathbf{R}_{\mathbf{O}}$ & SI & $\mathbf{R}_{\mathbf{O}}$ \\
\hline 19 & $\begin{array}{l}\text { Inadequate comprehension of scope of work at the } \\
\text { bidding stage }\end{array}$ & 3.58 & 1 & 4 & 3.36 & 7 & 3.6 & 7 & 3.77 & 2 \\
\hline 20 & Subcontractor-related problems & 3.20 & 6 & 22 & 3.2 & 13 & 3.4 & 16 & 3 & 29 \\
\hline 21 & Rework due to errors during construction & 3.18 & 7 & 24 & 2.6 & 32 & 3.4 & 18 & 3.54 & 9 \\
\hline 22 & Underbidding & 3.38 & 3 & 11 & 3 & 21 & 3.56 & 11 & 3.58 & 8 \\
\hline 23 & Unreasonable adjustment of project cost by contractors & 3.00 & 8 & 29 & 3 & 27 & 3 & 34 & 3 & 30 \\
\hline \multicolumn{11}{|c|}{ External-related causes } \\
\hline 24 & Variations in market conditions & 2.96 & 1 & 33 & 3.3 & 8 & 2.7 & 37 & 2.88 & 33 \\
\hline 25 & Cost inflation of machinery & 2.73 & 2 & 36 & 2.5 & 34 & 2.89 & 35 & 2.8 & 36 \\
\hline 26 & Impact of hot weather on construction work & 2.47 & 3 & 37 & 2.3 & 37 & 2.6 & 38 & 2.5 & 37 \\
\hline \multicolumn{11}{|c|}{ Owner-related causes } \\
\hline 27 & Adoption of fast-track project delivery strategy & 3.00 & 7 & 30 & 2.89 & 28 & 3.22 & 26 & 2.88 & 35 \\
\hline 28 & Deficient documentation and incomplete scope definition & 3.40 & 3 & 10 & 3.36 & 6 & 3.2 & 27 & 3.64 & 6 \\
\hline 29 & $\begin{array}{l}\text { Changing of design and scope by client during } \\
\text { construction }\end{array}$ & 3.79 & 1 & 1 & 3.91 & 1 & 3.8 & 2 & 3.65 & 5 \\
\hline 30 & Long project approval procedures & 3.02 & 6 & 28 & 3.09 & 20 & 3.1 & 31 & 2.88 & 34 \\
\hline 31 & Many stakeholders & 3.22 & 5 & 20 & 3.1 & 19 & 3.6 & 9 & 2.96 & 31 \\
\hline 32 & Poor definition of subsurface data & 2.97 & 8 & 32 & 2.78 & 30 & 3.2 & 28 & 2.92 & 32 \\
\hline 33 & The lowest bid price system & 3.33 & 4 & 15 & 3.27 & 11 & 3.3 & 21 & 3.42 & 16 \\
\hline 34 & $\begin{array}{l}\text { Underestimating of cost and schedules/overestimating } \\
\text { of benefits }\end{array}$ & 3.49 & 2 & 5 & 3.18 & 17 & 3.5 & 14 & 3.79 & 1 \\
\hline \multicolumn{11}{|c|}{ Resources-related causes } \\
\hline 35 & Labors' lack of skills and productivity & 2.96 & 4 & 34 & 2.33 & 36 & 3.1 & 33 & 3.44 & 12 \\
\hline 36 & Lack of equipment & 2.98 & 3 & 31 & 2.75 & 31 & 3.11 & 30 & 3.09 & 26 \\
\hline 37 & Manpower shortage & 3.17 & 2 & 25 & 3 & 24 & 3.4 & 17 & 3.12 & 25 \\
\hline 38 & Material procurement issues & 3.48 & 1 & 6 & 3.27 & 12 & 3.7 & 4 & 3.48 & 10 \\
\hline
\end{tabular}

Note: SI: significance index; $\mathrm{R}_{\mathrm{G}}=$ group ranking; $\mathrm{R}_{\mathrm{O}}=$ overall ranking. 
The overall ranking of the 29 causes of time overruns in the oil and gas industry are presented in Table 3. The findings revealed that "changing of design and scope by client during construction", which appears in the "owner-related causes" category, was the most significant cause contributing to time overrun. This finding is sensible. In particular, oil and gas projects are highly complex and demand considerable investment in design prior to the commencement of the construction stage. When clients either change the design or scope during the construction stage, the subsequent disruption in the workflow can seriously jeopardize the timely completion of the project. This is owing to the significant design coordination required to accommodate any downstream design changes. The coordination efforts will consume significant design time and result in idle time in the construction site as contractors await further instructions. The least significant cause of time overrun was found to be "personality clash between two or more members from different parties".

Table 3. Causes of time overrun.

\begin{tabular}{|c|c|c|}
\hline No. & Causes & SI \\
\hline \multicolumn{3}{|c|}{ All Parties-related causes } \\
\hline 1 & Incompetent project team & 3.35 \\
\hline 2 & Personality clash between two or more members from different parties & 2.40 \\
\hline 3 & Poor planning and scheduling of project & 3.72 \\
\hline \multicolumn{3}{|c|}{ Consultant/designer-related causes } \\
\hline 4 & Design errors & 3.65 \\
\hline 6 & Inadequate quality control/assurance & 3.34 \\
\hline 8 & Inadequate management of contractor's schedule by consultant & 3.03 \\
\hline 9 & Unforeseen conditions and structural modifications & 3.29 \\
\hline 10 & Weak and insufficient technical studies & 3.28 \\
\hline \multicolumn{3}{|c|}{ Contract-related causes } \\
\hline 11 & Poor communication among the parties & 3.48 \\
\hline 12 & Discrepancies in contract documents & 3.19 \\
\hline 13 & Poorly defined payment milestones & 3.10 \\
\hline 14 & $\begin{array}{l}\text { Lack of communication with suppliers in the engineering and } \\
\text { procurement phases }\end{array}$ & 3.45 \\
\hline \multicolumn{3}{|c|}{ Contractor-related causes } \\
\hline 15 & Financing project by contractor during construction & 2.93 \\
\hline 16 & Inadequate or insufficient contractor experience & 3.30 \\
\hline 17 & Poor project implementation strategies & 3.20 \\
\hline 18 & Inadequate management and supervision of site & 3.42 \\
\hline 19 & Inadequate comprehension of scope of work at the bidding stage & 3.58 \\
\hline 20 & Subcontractor-related problems & 3.20 \\
\hline 21 & Rework due to errors during construction & 3.18 \\
\hline \multicolumn{3}{|c|}{ External-related causes } \\
\hline 26 & Impact of hot weather on construction work & 2.47 \\
\hline \multicolumn{3}{|c|}{ Owner-related causes } \\
\hline 28 & Deficient documentation and incomplete scope definition & 3.40 \\
\hline 29 & Changing of design and scope by client during construction & 3.79 \\
\hline 30 & Long project approval procedures & 3.02 \\
\hline 31 & Many stakeholders & 3.22 \\
\hline 32 & Poor definition of subsurface data & 2.97 \\
\hline \multicolumn{3}{|c|}{ Resources-related causes } \\
\hline 35 & Labors' lack of skills and productivity & 2.96 \\
\hline 36 & Lack of equipment & 2.98 \\
\hline 37 & Manpower shortage & 3.17 \\
\hline 38 & Material procurement issues & 3.48 \\
\hline
\end{tabular}


The overall ranking of the nine causes of cost overrun in the oil and gas industry is presented in Table 4. The findings indicate that "underestimating of cost and schedules/overestimating of benefits", which comes under the "owner-related causes" category, was the most significant factor contributing to cost overruns. This finding shows that these projects typically incur cost overrun because of poor cost and schedule estimation conducted by the owner's team. Conversely, "cost inflation of machinery" was found to be the least significant factor responsible for cost overrun. This appears to be a valid finding since the cost of machinery remains stable and is not prone to price fluctuations.

Table 4. Causes of cost overrun.

\begin{tabular}{ccc}
\hline No. & Causes & SI \\
\hline & Consultant/designer-related causes & \\
5 & Inadequate cost estimating approach /inaccurate material estimation & 3.34 \\
7 & Negligence of site visits before/during the bidding process & 3.32 \\
22 & Underbidding & 3.38 \\
23 & Unreasonable adjustment of project cost by contractors & 3.00 \\
\hline & External-related causes \\
24 & Variations in market conditions & 2.96 \\
27 & Cost inflation of machinery & 2.73 \\
33 & Owner-related causes & 3.00 \\
34 & Adoption of fast-track project delivery strategy & 3.33 \\
\hline
\end{tabular}

\section{Discussion}

It is crucial to have an understanding of the parties and/or conditions that play a major role in contributing to time and cost overruns. In doing so, appropriate measures can be framed to mitigate time and cost overruns of these large projects.

Table 5 presents the seven major categories along with their significance index and ranking. It can be seen from this table that the two most significant categories were "consultant/designer-related causes" and "contract-related causes". This finding indicates the significance of having in place a robust communication system, where the responsibilities and rights of the various parties are clearly articulated. This finding also further supports the previous observation of the importance of the design stage to the success of projects in this industry. In particular, since these projects mandate the close collaboration of many disciplines, coordination and integration become more critical. The least significant category, on the other hand, was found to be the "external-related causes". Two of the causes under this category pertain to the stability of the market, namely, "variations in market conditions" and "cost inflation of machinery". Since the economy of Saudi Arabia is stable, these causes are not significant-hence, their low ranking by the respondents. The other cause in this category, "Impact of hot weather on construction work", was also ranked among the least significant cause, since contractors operating in Saudi Arabia have learned to cope with the high temperatures making this cause controllable. 
Table 5. Significance index and ranking of categories.

\begin{tabular}{cccc}
\hline Category. & No. Causes & SI & Rank \\
\hline All Parties & 3 & 3.16 & 5 \\
Consultant & 7 & 3.32 & 1 \\
Contract & 4 & 3.30 & 2 \\
Contractor & 9 & 3.24 & 4 \\
External & 3 & 2.72 & 7 \\
Owner & 8 & 3.28 & 3 \\
Resources & 4 & 3.15 & 6 \\
\hline
\end{tabular}

Note: SI: significance index.

\section{Test of Agreement}

To test the degree of agreement (or disagreement) among the different parties with regards to the significance of the 38 identified causes of time and cost overrun, the Spearman Rank correlation was employed [41]:

$$
\mathrm{r}_{\mathrm{s}}=1-\frac{\sum_{1}^{38} \mathrm{~d}_{\mathrm{i}}^{2}}{\mathrm{n}\left(\mathrm{n}^{2}-1\right)}
$$

where $r_{s}$ : Spearman's rank correlation value, $d_{i}^{2}$ : difference between the ranks of each observation for the two variables, and $\mathrm{N}$ : number of observations in one set of variables (or number of ranked factors).

The results indicated a $50.69 \%$ agreement between owners and consultant, $54.98 \%$ between consultants and contractors, and $48.27 \%$ agreement between owners and contractors.

\section{Conclusions and Recommendations}

This study identified and assessed the causes of time and cost overrun in the Saudi Arabian oil and gas construction industry. In total, 38 causes were identified through an in-depth review of literature, supplemented by an interview with an expert in this field. These causes were grouped into seven categories, including "all parties-related causes", "consultant-related causes", "contract-related causes", "contractor-related causes", "external-related causes", "owner-related causes", and "resources-related causes". The result of the responses indicated that that the five most significant causes were "changing of design and scope by client during construction", "poor planning and scheduling of project", "design errors", "Inadequate comprehension of scope of work at the bidding stage", and "underestimating of cost and schedules/overestimating of benefits".

The study recommends the following course of action to prevent the causes of time and cost overrun in oil and gas construction projects:

- The present study revealed that "changing of design and scope by client during construction" was the most significant cause of time and cost overrun. This finding suggests that it is of high significance that clients are aware that any change of scope, once the construction of these types of projects has commenced, can be extremely disruptive to the smooth progression of the project. The present study therefore recommends that clients invest sufficient time and funds in selecting the appropriate consultants. Once the proper consultant has been engaged, clients should ensure that their design intentions are understood by consultants.

- The present study concluded that "poor planning and scheduling of project" was among the most significant causes of time and cost overrun. In light of this finding, the study recommends that more attention should be directed at early stages of these projects. In addition, qualified personnel at managerial levels should be assigned to sensitive projects for proper planning of these projects. This should be followed by close monitoring to ensure that the time and cost of the actual project does not deviate from the planned project. Furthermore, periodical meetings should be conducted to ensure proper communication among parties [42]. 
- According to the findings, the two causes "Inadequate comprehension of scope of work at the bidding stage", and "underestimating of cost and schedules/overestimating of benefits" were among the most significant causes of time and cost overrun. Therefore, the study recommends the adoption of an alternative bidding system other than the lowest bidder system. For example, the bidding system could be improved by conducting detailed analysis of contractors who would otherwise be disqualified by the lowest bidder system. Furthermore, extensive interviews with bidders in order to clarify vague or unclear issues that should be undertaken. Such precautionary measures could save significant costs during the construction stage and minimize the causes of time and cost overrun associated with unqualified contractors.

- Based on the findings of the present research which, indicated "design errors" as a significant cause of time and cost overrun, the study recommends that consultants develop a system for checking design before the commencement of construction. Moreover, consultants should focus on implementing a proper coordination system between different engineering departments. This is owing to the fact that one of the important causes of design errors in oil and gas construction projects is poor integration between different engineering disciplines.

Since time and cost overrun causes are highly correlated, the present study treated these two groups of factors as a single factor. However, it is acknowledged that the main causes and the impacts of schedule delay and cost overrun can differ from each other. Thus, future studies should explore the degree to which the identified factors affect time and cost separately in order to determine the relationship between these two issues. Limitations notwithstanding, the findings of this study can be of great benefit to the various stakeholders operating in the Saudi Arabian oil and gas construction industry by offering a ranked list of the major causes of time and cost overrun. This gained insight will empower the stakeholders to better manage these projects, since time and energy can be more effectively and efficiently directed at avoiding the most significant causes of time and cost overruns. The outcome of this effort will be reduced time and cost overrun of projects, which in turn will contribute significantly to the economy.

Author Contributions: A.B.S. collected and analyzed the data, and wrote the original manuscript; S.A. and M.A.H. developed the methodology and supervised the research; and A.A. reviewed the data, updated the literature and edited the final manuscript.

Acknowledgments: The authors thank King Fahd University of Petroleum and Minerals for the support and facilities that made this research possible.

Conflicts of Interest: The authors declare no conflict of interest.

\section{References}

1. Oberlender, G.D. Project Management for Engineering and Construction; McGraw-Hill: New York, NY, USA, 1993.

2. Jackson, S. Project cost overruns and risk management. In Proceedings of the 18th Annual ARCOM Conference, Association of Researchers in Construction Management, Northumbria University, Newcastle, UK, 2-4 September 2002; pp. 1-10.

3. Ahmed, S.M.; Azhar, S.; Castillo, M.; Kappagantula, P. Construction Delays in Florida: An Empirical Study; Final Report; Department of Community Affairs: Miami, FL, USA, 2002.

4. Oil and Gas Industry Profile: Saudi Arabia. 2016, pp. 1-41. Available online: https:/ /www.projectguru.in/ publications/oil-gas-industry-saudi-arabia/ (accessed on 30 December 2016).

5. International Energy Agency (IEA). World Energy Outlook; International Energy Agency: Paris, France, 2006.

6. Dey, P.K. Project risk management using multiple criteria decision-making technique and decision tree analysis: A case study of Indian oil refinery. Prod. Plan. Control 2012, 23, 903-921. [CrossRef]

7. Kaming, P.F.; Olomolaiye, P.O.; Holt, G.D.; Harris, F.C. Factors influencing construction time and cost overruns on high-rise projects in Indonesia. Constr. Manag. Econ. 1997, 15, 83-94. [CrossRef]

8. Flyvbjerg, B.; Skamris-Holm, M.K.; Buhl, S.L. What causes cost overrun in transport infrastructure projects? Transp. Rev. 2004, 24, 3-18. [CrossRef] 
9. Assaf, S.A.; Al-Hajji, S. Causes of delay in large construction projects. Int. J. Proj. Manag. 2006, $24,349-357$. [CrossRef]

10. Lo, T.Y.; Fung, I.W.; Tung, K.C. Construction delays in Hong Kong civil engineering projects. J. Constr. Eng. Manag. 2006, 132, 636-649. [CrossRef]

11. Merewitz, L. Cost Overruns in Public Works; Institute of Urban and Regional Development, University of California: Berkeley, CA, USA, 1973.

12. Arditi, D.; Gunaydin, H.M. Total quality management in the construction process. Int. J. Proj. Manag. 1997, 15, 235-243. [CrossRef]

13. Atkinson, R. Project management: Cost, time and quality, two best guesses and a phenomenon, its time to accept other success criteria. Int. J. Proj. Manag. 1999, 17, 337-342. [CrossRef]

14. Songer, A.D.; Molenaar, K.R. Project characteristics for successful public-sector design-build. J. Constr. Eng. Manag. 1997, 123, 34-40. [CrossRef]

15. Avotos, I. Cost-relevance analysis for overrun control. Int. J. Proj. Manag. 1983, 1, 142-148. [CrossRef]

16. Liu, L.; Zhu, K. A Stage-by-stage factor control framework for cost estimation of construction projects. J. Constr. Eng. Manag. 2007, 133, 91-95. [CrossRef]

17. Aibinu, A.; Jagboro, G. The effects of construction delays on project delivery in Nigerian construction industry. Int. J. Proj. Manag. 2002, 20, 593-599. [CrossRef]

18. Sambasivan, M.; Soon, Y.W. Causes and effects of delays in Malaysian construction industry. Int. J. Proj. Manag. 2007, 25, 517-526. [CrossRef]

19. Morris, S. Cost and time overruns in public sector projects. Econ. Political Wkly. 1990, 25, M154-M168.

20. Le-Hoai, L.; Lee, Y.D.; Lee, J.Y. Delay and cost overruns in Vietnam large construction projects: A comparison with other selected countries. KSCE J. Civ. Eng. 2008, 12, 367-377. [CrossRef]

21. Alinaitwe, H.; Apolot, R.; Tindiwensi, D. Investigation into the causes of delays and cost overruns in Uganda's public sector construction projects. J. Constr. Dev. Ctries. 2013, 18, 33-47.

22. Flyvbjerg, B.; Skamris-Holm, M.K.; Buhl, S.L. How common and how large are cost overruns in transport infrastructure projects? Transp. Rev. 2013, 23, 71-88. [CrossRef]

23. Bella, A.B. Cost Overruns and Time Delays in Highway and Bridge Projects in Developing Countries-Experiences from Cameroon. Master's Thesis, Michigan State University, East Lansing, MI, USA, 2011.

24. Mansfield, N.R.; Ugwu, O.O.; Doran, T. Causes of delay and cost overruns in Nigerian construction projects. Int. J. Proj. Manag. 1994, 12, 254-260. [CrossRef]

25. Frimpong, Y.; Oluwoye, J.; Crawford, L. Causes of delay and cost overruns in construction of groundwater projects in a developing countries; Ghana as a case study. Int. J. Proj. Manag. 2003, 21, 321-326. [CrossRef]

26. Enshassi, A.; AlNajjar, J.; Kumaraswamy, M. Delays and cost overruns in the construction projects in the Gaza strip. J. Financ. Manag. Prop. Constr. 2009, 14, 126-151. [CrossRef]

27. Abd El-Razek, M.E.; Bassioni, H.A.; Mobarak, A.M. Causes of delay in building construction projects in Egypt. J. Constr. Eng. Manag. 2008, 134, 831-841. [CrossRef]

28. Al-Khalil, M.I.; Al-Ghafly, M.A. Important causes of delay in public utility projects in Saudi Arabia. Constr. Manag. Econ. 1999, 17, 647-655. [CrossRef]

29. Zamel, S.A.I. Construction Cost Control in the Eastern Province of Saudi Arabia. Master's Thesis, King Fahd University of Petroleum and Minerals, Dhahran, Saudi Arabia, 1991.

30. Al-Dubaisi, A.H. Change Orders in Construction Projects in Saudi Arabia. Master's Thesis, King Fahd University of Petroleum and Minerals, Dhahran, Saudi Arabia, 2000.

31. Thuyet, N.V.; Ogunlana, S.O.; Dey, P.K. Risk management in oil and gas construction projects in Vietnam. Int. J. Energy Sector Manag. 2007, 1, 175-194. [CrossRef]

32. Fallahnejad, M.H. Delay causes in Iran gas pipeline projects. Int. J. Proj. Manag. 2013, 31, 136-146. [CrossRef]

33. Ruqaishi, M.; Bashir, H.A. Causes of delay in construction projects in the oil and gas industry in the gulf cooperation council countries: A case study. J. Manag. Eng. 2013, 31, 05014017. [CrossRef]

34. Derakhshanalavijeh, R.; Teixeira, J.M.C. Cost overrun in construction projects in developing countries, gas-oil industry of Iran as a case study. J. Civ. Eng. Manag. 2017, 23, 125-137. [CrossRef]

35. Kaliba, C.; Muya, M.; Mumba, K. Cost Escalation and Schedule Delays in Road Construction Projects in Zambia. Int. J. Proj. Manag. 2009, 27, 522-531. [CrossRef] 
36. Shehu, Z.; Endut, I.R.; Akintoye, A. Factors Contributing to Project Time and Hence Cost Overrun in the Malaysian Construction Industry. J. Financ. Manag. Prop. Constr. 2014, 19, 55-75. [CrossRef]

37. Kikwasi, G. Causes and Effects of Delays and Disruptions in Construction Projects in Tanzania. Australasian J. Constr. Econ. Build. Conf. Ser. 2013, 1, 52-59. [CrossRef]

38. Dominowski, R.L. Research Methods; Prentice-Hall: Englewood Cliff, NJ, USA, 1980.

39. Enshassi, A.; Mohamed, S.; El Karriri, A.A. Factors Affecting the Bid/No Bid Decision in the Palestinian Construction Industry. J. Financ. Manag. Prop. Constr. 2010, 15, 118-142. [CrossRef]

40. Bagaya, O.; Song, J. Empirical Study of Factors Influencing Schedule Delays of Public Construction Projects in Burkina Faso. J. Manag. Eng. 2016, 32. [CrossRef]

41. Aczel, A.D.; Sounderpandian, J.; Saravanan, P.; Rohit, J. Complete Business Statistics, 7th ed.; McGraw-Hill: Boston, MA, USA, 2012.

42. Al-Sofi, M. Interview, Executive Managing Partner at the Arabian Consulting Engineering Center (ACEC); ACEC: Khobar, Saudi Arabia, 2017.

(C) 2019 by the authors. Licensee MDPI, Basel, Switzerland. This article is an open access article distributed under the terms and conditions of the Creative Commons Attribution (CC BY) license (http:/ / creativecommons.org/licenses/by/4.0/). 